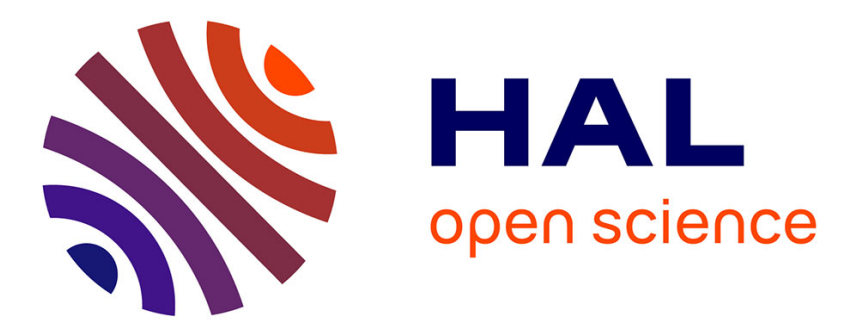

\title{
Star-shaped conjugated systems derived from dithiafulvenyl-derivatized triphenylamines as active materials for organic solar cells
}

Olivier Alévêque, Philippe Leriche, Nicolas Cocherel, Pierre Frère, Antonio Cravino, Jean Roncali

\section{To cite this version:}

Olivier Alévêque, Philippe Leriche, Nicolas Cocherel, Pierre Frère, Antonio Cravino, et al.. Starshaped conjugated systems derived from dithiafulvenyl-derivatized triphenylamines as active materials for organic solar cells. Solar Energy Materials and Solar Cells, 2008, 92 (9), pp.1170 - 1174. 10.1016/j.solmat.2008.04.006 . hal-03027832

\section{HAL Id: hal-03027832 \\ https://univ-angers.hal.science/hal-03027832}

Submitted on 27 Nov 2020

HAL is a multi-disciplinary open access archive for the deposit and dissemination of scientific research documents, whether they are published or not. The documents may come from teaching and research institutions in France or abroad, or from public or private research centers.
L'archive ouverte pluridisciplinaire HAL, est destinée au dépôt et à la diffusion de documents scientifiques de niveau recherche, publiés ou non, émanant des établissements d'enseignement et de recherche français ou étrangers, des laboratoires publics ou privés. 


\title{
Star-shaped conjugated systems derived from dithiafulvenyl-derivatized triphenylamines as active materials for organic solar cells
}

\author{
Olivier Alévêque, Philippe Leriche*, Nicolas Cocherel, Pierre Frère, Antonio Cravino, Jean Roncali \\ Université d'Angers, CNRS, Laboratoire de Chimie et Ingénierie Moléculaire d'Angers, CIMA, Group linear conjugated systems, 2 Bd Lavoisier, 59045 Angers, France
}

\section{A R T I C L E I N F O}

\section{Article history:}

Received 15 February 2008

Received in revised form

10 April 2008

Accepted 10 April 2008

Available online 2 June 2008

Keywords:

Triphenylamine

Tetrathiafulvalene

Star-shaped Systems

Solar cells

\begin{abstract}
A B S T R A C T
Hybrid conjugated systems consisting of a triphenylamine core substituted by three dithiafulvenyl moieties have been synthesized and tested as active materials in organic field-effect transistors and photovoltaic devices. UV-vis. spectroscopy studies demonstrate that, despite their amorphous character shown by X-ray diffraction and differential scanning calorimetry, strong interactions exist in these materials as an aggregative band is observed at low energies. A first evaluation of their potentialities as $p$ semiconductor in organic field-effect transistors shows significant hole mobilities. For bilayer photovoltaic devices, a power conversion efficiency of $0.11 \%$ is observed and the external quantum efficiency of the cell under monochromatic irradiation shows a non-negligible contribution of the aggregative band.
\end{abstract}

(c) 2008 Elsevier B.V. All rights reserved.

\section{Introduction}

Organic solar cells are subject to a considerable current interest motivated by the perspective of achieving large-area, low-cost, light-weight and flexible power sources with a reduced environmental impact [1-5]. Power conversion efficiencies in the 4.5-5\% range have recently been reported for bulk heterojunction solar cells based on regioregular poly(3-hexylthiophene) (P3HT) and $[6,6]-$ phenyl- $C_{61}$-butyric acid methyl ester (PCBM) [6-8]. In spite of these good performances, P3HT poses a number of problems related to the control of its regio-regularity, molecular weight and polydispersity. Furthermore the high external quantum efficiency reached by P3HT cells suggests that the high power conversion efficiencies recently published could be close to the limit imposed by the electronic properties of this polymer.

A possible alternative to conjugated polymers could consist in the development of amorphous molecular materials based on monodisperse precursors easy to synthesize and to purify [9]. In this context, we have recently described a series of triphenylamine (TPA) pseudo-three-dimensional conjugated architectures leading to organic glasses with interesting hole mobilities when used in organic field-effect transistors (OFETs) [10]. Furthermore, we have shown that the creation of an internal charge transfer in those systems leads to active materials for solar cells combining extended spectral response, improved open-circuit voltage and stability [11-13].

Tetrathiafulvalene (TTF) derivatives have been known for years to form one-dimensional stacks propitious for high-efficiency

\footnotetext{
* Corresponding author. Tel.: +33241735010; fax: +33241735405.

E-mail address: philippe.leriche@univ-angers.fr (P. Leriche).
}

intermolecular charge-carrier mobility [14,15]. Recently, hole mobilities as high as 1.40 and $0.38 \mathrm{~cm}^{2} \mathrm{~V}^{-1} \mathrm{~s}^{-1}$ have been reported for OFETs based on single crystals or evaporated thin films of TTF derivatives, respectively [16-18].

In our continuing interest for TPA-based organic semiconductors, we report here a first analysis of the performances of OFETs and solar cells based on hybrid dithiafulvenyl-triphenylamine systems. Thus, the propensity of TTF to self-assemble may lead to new donor materials in which the combination of the structural features and electronic properties of TPA and TTF may lead to materials with enhanced intermolecular interactions. Two conjugated systems in which three substituted dithiafulvenyl units are grafted on a TPA core $(\mathbf{1}, \mathbf{2})$ have been synthesized. For compound 1, the fusion of a benzenic ring with the dithiafulvenyl moiety may lead to reinforced intermolecular interactions in the solid state while the methylsulfanyl group for compound $\mathbf{2}$ may contribute to ensure sufficient solubility for spin coating.

The electronic properties of these compounds have been characterized by cyclic voltammetry, UV-vis spectroscopy, X-ray diffraction and differential scanning calorimetry (DSC) and a first evaluation of their potentialities in OFETs and solar cells is presented.

\section{Experimental}

\subsection{General methods}

Solvents were purified and dried using standard protocols. ${ }^{1} \mathrm{H}$ NMR and ${ }^{13} \mathrm{C}$ NMR spectra were recorded on a Bruker AVANCE DRX 500 spectrometer operating at 500.13 and $125.7 \mathrm{MHz} ; \delta$ are 
given in ppm (relative to TMS) and coupling constants $J$ in $\mathrm{Hz}$. Matrix-assisted laser desorption ionization time-of-flight (MALDITOF) mass spectra were recorded by a Bruker Biflex-III, equipped with a $\mathrm{N}_{2}$ laser (337 nm). For the matrix, dithranol in $\mathrm{CH}_{2} \mathrm{Cl}_{2}$ was used. High-resolution mass spectra were recorded under FAB mode on a Jeol JMS 700 spectrometer. UV-visible optical data were recorded with a Perkin-Elmer lambda 19 spectrophotometer. Thermal analyses were performed using a DSC 2010 CE (TA Instruments). X-ray diffraction experiments were carried out in $\theta-2 \theta$ reflection mode using a Bruker D500 diffractometer equipped with a speed detector Vantec. For cyclic voltammetry (scan rate $100 \mathrm{mV} \mathrm{cm}^{-1}$ ), the electrochemical apparatus consisted of a potentiostat EG\&G PAR 273A and a standard three-electrode cell. As working and counter electrodes, a platinum foil and a platinum wire were used, respectively, while an $\mathrm{Ag} / \mathrm{AgCl}$ electrode served as reference.

\subsection{Device preparation and characterization}

Fullerene C60 (99+\%) was purchased from MER and used as received. The Baytron suspension was used to apply smoothing and hole conducting/injecting layers were "Baytron P PE FL" (HC Stark). All thin-film devices were prepared in laboratory conditions. As electrodes, ITO-coated glasses $\left(<20 \Omega \square^{-1}\right.$, Merck) and evaporated Al films (ca. $60 \mathrm{~nm}$ thick) were used. The ITO electrodes were cleaned in ultrasonic baths and then modified by a spun-cast layer of Baytron (60-80 nm thick), which were dried at $130^{\circ} \mathrm{C}$ for $20 \mathrm{~min}$. The Baytron suspension was stirred and filtered through a $0.45-\mu \mathrm{m}$ membrane (Minisart RC 15, Sartorius) just prior to casting. A $60 \mathrm{~nm}$ thick layer of Al was thermally evaporated through a shadow mask, at a pressure of about $10^{-6}$ mbar. The mask geometry defined a device's area of $0.29 \mathrm{~cm}^{2}$. Each plaque of ITO-coated glass supported two individual devices. After preparation, the devices were stored and characterized in an argon glovebox (200B, MBraun). The $J-V$ curves of the devices were recorded in the dark and under illumination using a Keithley 236 source-measure unit and a homemade acquisition program. The light source was an AM1.5 Solar Constant 575 PV simulator (Steuernagel Lichttecknik, equipped with a metal halogenide lamp). The light intensity was measured by a broad-band power meter (13PEM001, Melles Griot). The devices were illuminated through the ITO electrode side. The efficiency values reported here are not corrected, either for the possible solar simulator spectral mismatch or for the reflection/absorbance of the glass/ITO/ Baytron-coated electrodes.

OFETs were prepared by evaporation of a $50 \mathrm{~nm}$ thick organic layer for $\mathbf{1}$ and by spin coating for $\mathbf{2}$ onto a Si $\mathrm{n++}$ wafer with a $200 \mathrm{~nm}$ thick $\mathrm{SiO}_{2}$ layer (Siltronix). As source and drain top contacts, $50 \mathrm{~nm}$ of Au were evaporated through a homemade shadow mask, defining a channel with $5000 \mu \mathrm{m}$ width and $70 \mu \mathrm{m}$ lengths. The characterization was carried out in the glovebox using an Agilent 4155C semiconductor parameter analyzer. The contacts were obtained by $\mathrm{W}$ tips (Signatone).

\subsubsection{Compound 1}

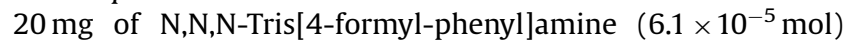
and 4 eq. of phosphonate $(64 \mathrm{mg})$ are dissolved in $10 \mathrm{~mL}$ of dry THF. The mixture is cooled at $0{ }^{\circ} \mathrm{C}$ and $0.15 \mathrm{~mL}$ of a $20 \%$ solution of $t$-BuOK in THF is dropped. After $1 \mathrm{~h}$, a mixture of methanol/water $(20 / 10 \mathrm{~mL})$ is added and the mixture is stirred for $10 \mathrm{~min}$. The yellow precipitate is filtered and successively washed with methanol and pentane; $42 \mathrm{mg}$ (95\% yield) of the yellow powder is collected.

MP $285^{\circ} \mathrm{C}$

RMN ${ }^{1} \mathrm{H}\left(\mathrm{CDCl}_{3}\right)$ : $7.23(\mathrm{~m}, 12 \mathrm{H})-7.11(\mathrm{~m}, 12 \mathrm{H})-6.51(\mathrm{~s}, 3 \mathrm{H})$.
RMN ${ }^{13} \mathrm{C}\left(\mathrm{CDCl}_{3}\right):$ 144.9-136.4-134.8-131.3-130.5-127.9-125.9125.5-124.0-121.7-120.9-114.3.

HRMS $\mathrm{M}^{+} \mathrm{C}_{42} \mathrm{H}_{27} \mathrm{NS}_{6}$ (calcd) (737.0468) 737.0469

\subsubsection{Compound 2}

$20 \mathrm{mg}$ of Tris N,N,N-Tris[4-formyl-phenyl]amine $\left(6.1 \times 10^{-5}\right.$ $\mathrm{mol})$ and 5 eq. of 4,5-dimethoxy-2-thioxo-1,3-dithiole $(68 \mathrm{mg}$ ) are suspended in $2 \mathrm{~mL}$ of toluene. The mixture is refluxed until complete dissolution, after which $1 \mathrm{~mL}$ of triethylphosphite is added. The solution turns rapidly red and is refluxed for one additional hour. After cooling to room temperature, the product is precipitated by addition of petroleum ether. The solid is then filtered, washed with petroleum ether and dried; $45 \mathrm{mg}(86 \%$ yield) of the yellow powder is collected.

MP $118^{\circ} \mathrm{C}$

$\mathrm{Rf}=0.4\left(\mathrm{EP} / \mathrm{CH}_{2} \mathrm{Cl}_{2} 2: 1\right)$

RMN ${ }^{1} \mathrm{H}$ (DMSO d6): $7.16\left(\mathrm{~d}, 6 \mathrm{H},{ }^{3} \mathrm{~J}=9 \mathrm{~Hz}\right)-7.0(\mathrm{~d}, 6 \mathrm{H}$,

$\left.{ }^{3} \mathrm{~J}=9 \mathrm{~Hz}\right)-5.75(\mathrm{~s}, 3 \mathrm{H})-2.44(\mathrm{~s}, 9 \mathrm{H})-2.40(\mathrm{~s}, 9 \mathrm{H})$

RMN ${ }^{13} \mathrm{C}\left(\mathrm{CDCl}_{3}\right): 144.2-130.7-128.6-127.8-126.6-123.7-122.2-$

114.6-18.3-18.1

$\mathrm{SM}$ (Malditof) $\mathrm{C}_{36} \mathrm{H}_{33} \mathrm{NS}_{12}$ :mes. $\mathrm{M}+: 862,8$, th.:862,9

HRMS $\mathrm{M}^{+} \mathrm{C}_{36} \mathrm{H}_{33} \mathrm{NS}_{12}$ (calcd.) (862.9262) 862.9263

\section{Results and discussion}

Compounds $\mathbf{1}$ and $\mathbf{2}$ have been obtained in good yield from $\mathrm{N}, \mathrm{N}, \mathrm{N}$-tris[4-formyl-phenyl]amine [19], by a threefold Wittig-Horner reaction with the corresponding phosphonate anion for $\mathbf{1}$ and by condensation with 4,5-dimethylsulfanyl-2-thioxo-1,3dithiole in the presence of triethylphosphite for $\mathbf{2}$ (Scheme 1) [20]. Both compounds were satisfactorily characterized by spectrometric analyses.

The cyclic voltammograms recorded in methylene chloride in the presence of $0.10 \mathrm{M} \mathrm{Bu}_{4} \mathrm{NPF}_{6}$ as supporting electrolyte show a first oxidation wave peaking at 0.56 and $0.51 \mathrm{~V}$ for $\mathbf{1}$ and $\mathbf{2}$, respectively. This difference is in agreement with the electronic effects of the substituents [21]. A more detailed analysis of the electrochemical properties of this class of compounds will be published elsewhere.

Fig. 1 shows the UV-vis absorption spectra of compounds $\mathbf{1}$ and $\mathbf{2}$ in methylene chloride solution and as thin films on glass. The spectrum of compound 1 shows a first band at $340 \mathrm{~nm}$ followed by a main absorption band with $\lambda_{\max }$ at $398 \mathrm{~nm}$ while the spectrum of 2 exhibits only a main absorption band with $\lambda_{\max }$ at $408 \mathrm{~nm}$. The first band in the spectrum of 1 can be ascribed to the fused benzodithiafulvenyl unit.

Due to poor solubility in common solvents, thin films of compounds 1 were prepared by thermal evaporation under high vacuum. In contrast, compound $\mathbf{2}$ was processed by spin coating from a dichlorobenzene solution. It must be stressed that this compound decomposes under the conditions of thermal evaporation, thus preventing the process of the two compounds using the same technique.

The spectrum of films of $\mathbf{2}$ is rather similar to the solution spectrum with, however, a slight blue shift of $\lambda_{\max }$ and a broadening of the absorption band. In contrast, the spectrum of films of $\mathbf{1}$ appears better resolved with the emergence of a vibronic fine structure accompanied by a red shift of $\lambda_{\max }$ compared to the solution spectrum. This spectrum also exhibits a broad band of weak intensity centered at ca. $550 \mathrm{~nm}$ (Fig. 1), which may reflect the development of strong $\pi-\pi$ intermolecular interactions in the solid state. The aggregative origin of this band is further supported by the increase of its intensity observed when methanol (a non-solvent) is added to a solution of $\mathbf{1}$ in methylene chloride (Fig. 2). 


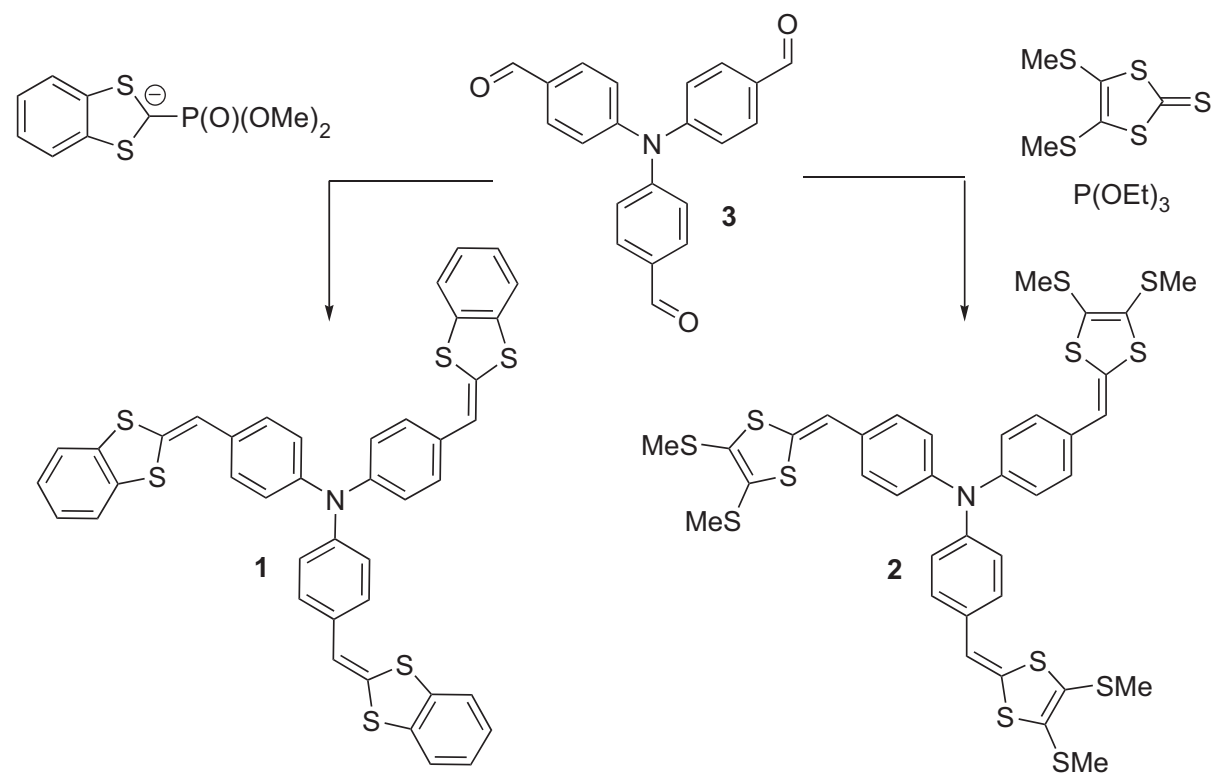

Scheme 1. Synthesis of compounds $\mathbf{1}$ and $\mathbf{2}$.
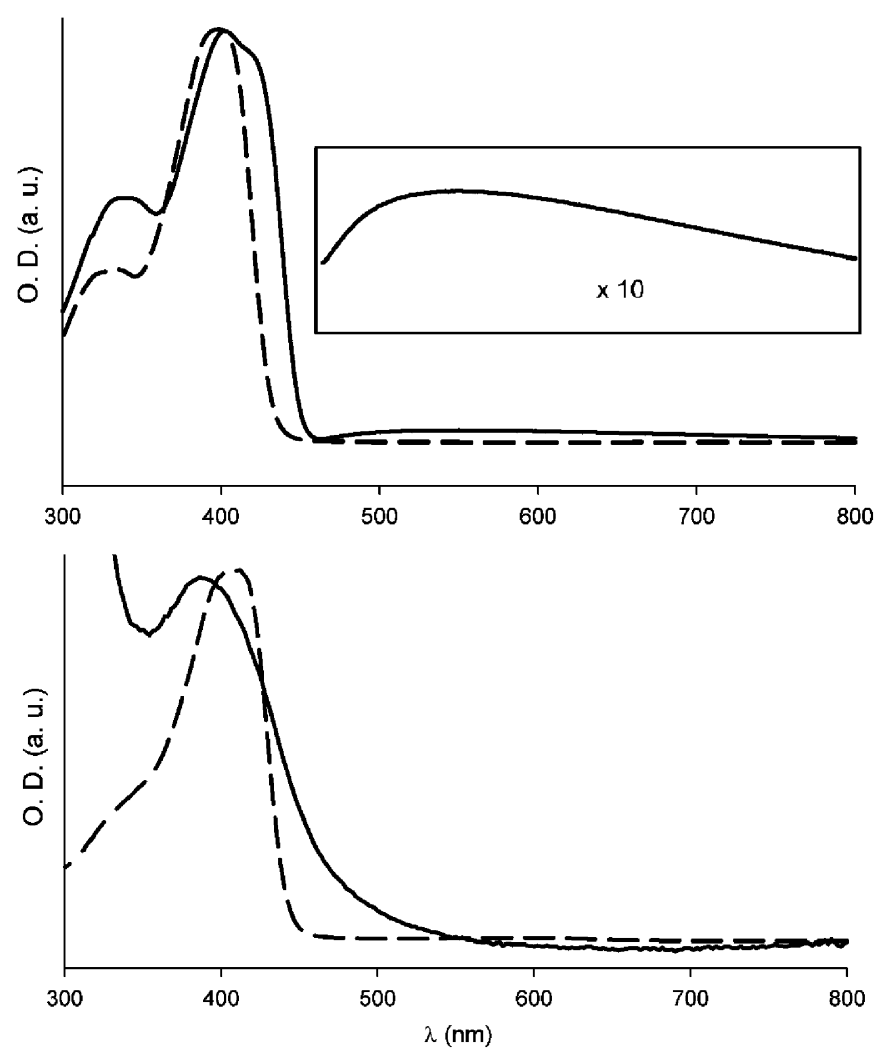

Fig. 1. UV-vis absorption spectra of $\mathbf{1}$ (top) and $\mathbf{2}$ (bottom) in solution (dotted lines) and as thin film deposited on glass (solid lines).

Films of the two compounds on glass have been investigated by X-ray diffraction in reflection mode. In both cases, the absence of reflection peak indicates an amorphous character. The analysis of the thermal properties of $\mathbf{1}$ and $\mathbf{2}$ by DSC shows that on the first scan, melting occurs at 285 and $118^{\circ} \mathrm{C}$ for, respectively, $\mathbf{1}$ and $\mathbf{2}$. On cooling and subsequent heating, an endothermic peak characteristic of a glass transition is observed at ca. 55 and $45^{\circ} \mathrm{C}$ for $\mathbf{1}$ and $\mathbf{2}$, respectively.

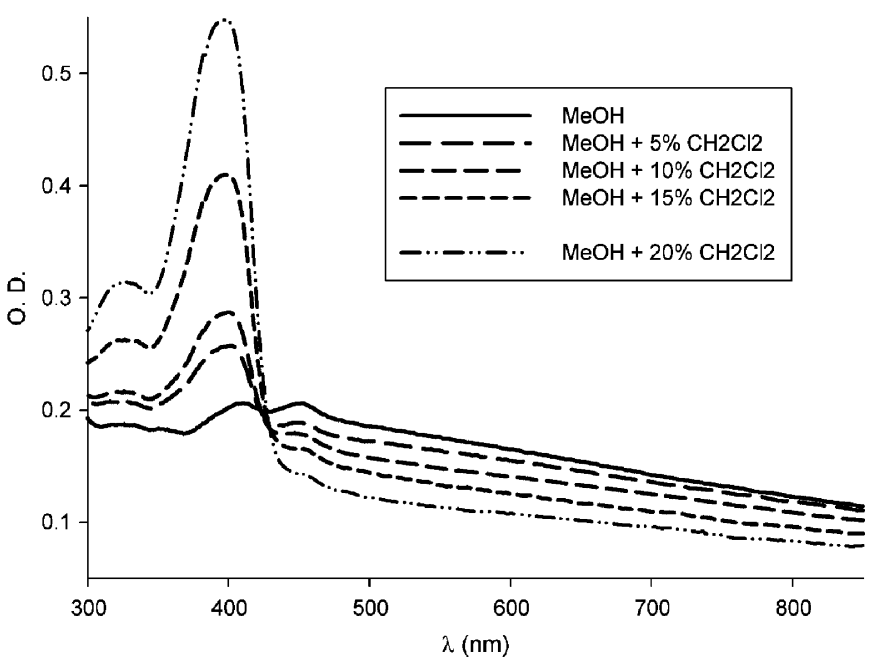

Fig. 2. UV-vis spectra of several solutions of $\mathbf{1}$ in methanol/methylenechloride mixtures.

The geometry of compound $\mathbf{1}$ has been optimized using the density functional theory at the B3LYP/6-31G(d) level (Fig. 3). As generally observed for TPA derivatives, the three central $\mathrm{N}-\mathrm{C}$ bonds are coplanar. Steric hindrance between the phenyl rings leads to the typical propeller shape of the molecule, which contributes to the amorphous character of TPA-based materials [22]. The benzodithiafulvenyl blocks are not coplanar with the benzene ring to which they are linked, thus reducing $\pi$-electron delocalization. The HOMO is delocalized on the whole molecule in agreement with the electron donor character of the dithiafulvenyl and TPA units. The LUMO is degenerated and mostly localized on two branches. The calculated HOMO-LUMO gap of $\mathbf{1}(3.37 \mathrm{eV})$ is in satisfactory agreement with optical data (3.12 eV in solution).

The potential of these compounds as active materials has been evaluated through the fabrication of OFETs and solar cells. OFETs were fabricated on a n-doped silicon gate with thermally grown $\mathrm{SiO}_{2}$ as dielectric and using a top-contact configuration. 
HOMO -4.43eV

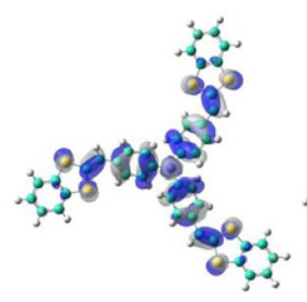

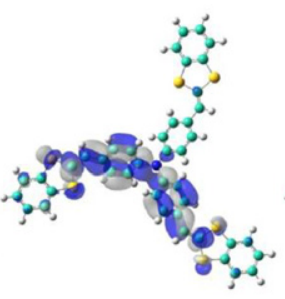

LUMO-1.06eV

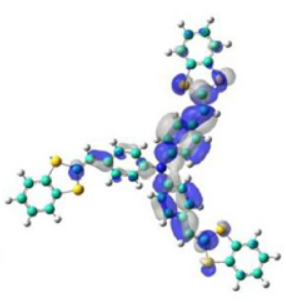

LUMO-1.06eV
Fig. 3. Optimized geometry, HOMO (left) and LUMO (middle and right) levels for compound 1.

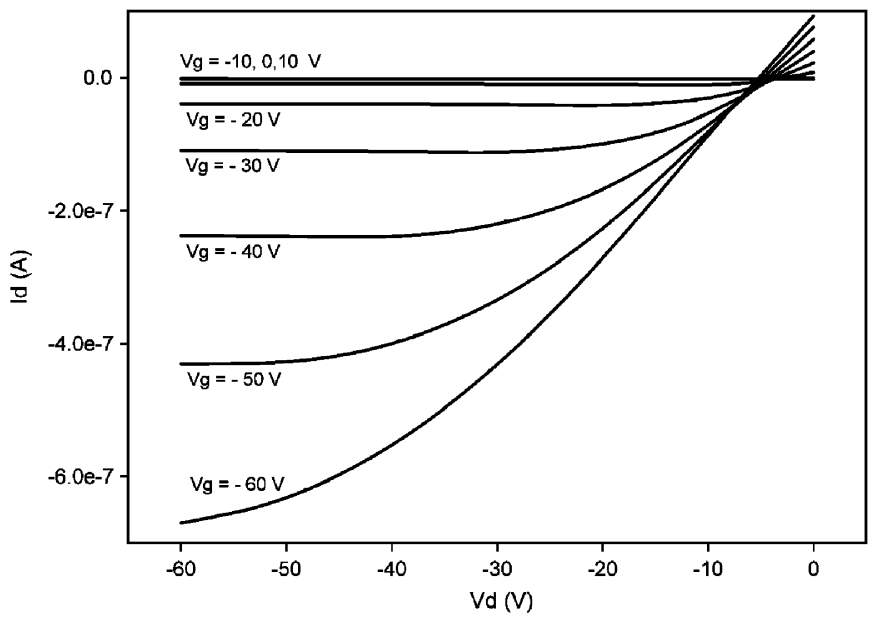

Fig. 4. $I_{\mathrm{SD}} / V_{\mathrm{SD}}$ curves at different $V_{\mathrm{G}}$ values for an OFET based on compound 1.

After deposition of the active layer (by thermal evaporation for $\mathbf{1}$ and spin coating for $\mathbf{2}$ ), source and drain electrodes were grown by evaporation of gold through a mask, leading to a channel of $70 \mu \mathrm{m}$ length and $5 \mathrm{~mm}$ width. The electrical characteristics were recorded at room temperature under inert atmosphere.

For both compounds, the characteristic displays a clear fieldeffect transistor (FET) behavior with well-defined linear and saturation regimes (Fig. 4). The amplification mode of the drain current $I_{\mathrm{d}}$ takes place when negative gate voltage $V_{\mathrm{g}}$ increases, as expected for a p-type semiconductor. The field-effect mobility $\mu_{E}$ was calculated from both linear and saturation current regimes with classical equations [23]. Compound 1 shows a hole mobility of $3.2 \times 10^{-4} \mathrm{~cm}^{2} \mathrm{~V}^{-1} \mathrm{~s}^{-1}$, ca. one order of magnitude higher than that of compound $\mathbf{2}$ (Table 1 ). This higher mobility of $\mathbf{1}$ could be related to stronger intermolecular $\pi$-stacking interactions in the solid state due to the presence of the fused benzodithiafulvenyl blocks. However, care should be observed when comparing the two compounds because of the different techniques used for material processing. Comparison of the values of the $I_{\mathrm{on}} / I_{\mathrm{off}}$ ratio reveals a considerably higher value for compound $\mathbf{2}$; until now we have not found any satisfying explanation for this unexpected result.

Conjugated systems containing TTF building blocks have been only scantly used as active material in organic solar cells [24-26]. Skabara and co-workers have reported a conversion efficiency of $0.13 \%$ for bulk heterojunction based on a polythiophene-TTF hybrid polymer system as donor [25]. More recently, Martín and co-workers have described a dyad combining a $\mathrm{C}_{60}$ unit linked to an extended TTF analog via a conjugated bridge and reported an efficiency of $0.03 \%$ for a single-layer device [26].
Table 1

Optical and electrochemical properties of compounds $\mathbf{1}$ and $\mathbf{2}$ and performances of OFETs built from $\mathbf{1}$ and $\mathbf{2}$

\begin{tabular}{llllll}
\hline Cmpd. & $\lambda_{\max }(\mathrm{nm})^{\mathrm{a}}$ & $\Delta E(\mathrm{eV})^{\mathrm{b}}$ & $E_{\mathrm{ox}}(\mathrm{V})^{\mathrm{c}}$ & $\mu_{E}\left(\mathrm{~cm}^{2} \mathrm{~V}^{-1} \mathrm{~s}^{-1}\right)$ & $I_{\text {on }} / I_{\text {off }}$ \\
& & & & & \\
\hline 1 & 398 & 2.70 & 0.56 & $3.2 \times 10^{-4}$ & 350 \\
2 & 408 & 2.60 & 0.51 & $5 \times 10^{-5}$ & $10^{4}$ \\
\hline
\end{tabular}

a $10^{-4} \mathrm{M}$ in $\mathrm{CH}_{2} \mathrm{Cl}_{2}$.

${ }^{\mathrm{b}}$ Band gap calculated from the edge of the absorption bands.

${ }^{c}$ Vs SCE, $<10^{-3} \mathrm{M}$ of compounds in $\mathrm{CH}_{2} \mathrm{Cl}_{2}$ with $0.1 \mathrm{M} \mathrm{Bu}_{4} \mathrm{NPF}_{6}$ as supporting electrolyte, scan rate $100 \mathrm{mV} \mathrm{s}^{-1}$.
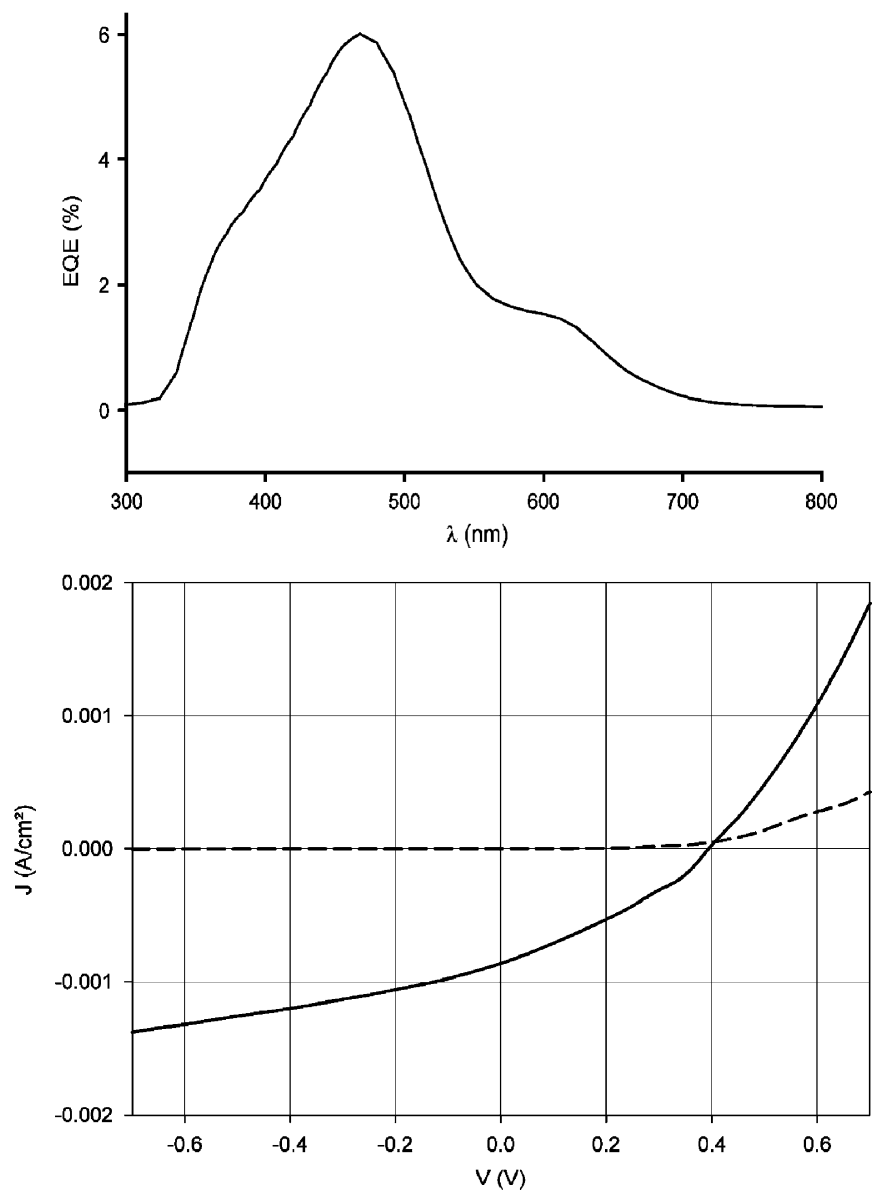

Fig. 5. (Top) External quantum efficiency of a bilayer heterojunction $1 / C_{60}$ under monochromatic irradiation; (bottom) current density vs voltage curve for the PV cell obtained from 1 and fullerene, in the dark (dotted line) and under simulated AM 1.5 solar irradiation at $100 \mathrm{~mW} \mathrm{~cm}^{-2}$ (line).

Compound $\mathbf{1}$ with the highest hole mobility has been evaluated as electron donor in bilayer heterojunction solar cells using fullerene $C_{60}$ as electron acceptor. The cells were realized by successive thermal evaporation of a film of $\mathbf{1}(20 \mathrm{~nm})$ and fullerene $(20 \mathrm{~nm})$ onto an ITO-coated glass electrode precoated with a film of Baytron P. The cell was completed by thermal evaporation of an aluminum top electrode.

Fig. 5 (top) shows the external quantum efficiency of the cell under monochromatic irradiation. The spectrum exhibits a first shoulder around $360 \mathrm{~nm}$, which may contain contributions of both the donor and $\mathrm{C}_{60}$. The maximum EQE of ca. $6 \%$ is observed at $470 \mathrm{~nm}$, while the spectrum also shows an additional 
photocurrent around $600 \mathrm{~nm}$, which can be attributed to the contribution of the already discussed aggregate species.

Under simulated solar irradiation at AM 1.5 conditions $\left(100 \mathrm{~mW} \mathrm{~cm}^{-2}\right.$, Fig. 5 (bottom)) the cell delivers a short-circuit current density $J_{\mathrm{SC}}$ of $0.87 \mathrm{mAcm}^{-2}$ and an open-circuit voltage $V_{\mathrm{OC}}$ of $0.40 \mathrm{~V}$. While this low voltage is consistent with the low oxidation potential (or high-lying HOMO level) of the donor $[27,28]$, the efficiency of the cell is essentially limited by the low value of the filling factor (FF) $\sim 32 \%$. These data lead to a power conversion efficiency of $0.11 \%$, a value quite comparable to the few available literature data for organic solar cells based on TTF derivatives [25,26]. Thin films of compounds 1 and 2 are stable for weeks when stored in ambient atmosphere. However, the solar cells show visible degradation after a few hours of irradiation in an inert atmosphere. These contrasting behaviors confirm that the stability of organic solar cells is not exclusively related to that of the active materials but requires specific optimization.

\section{Conclusion}

Two dithiafulvenyl-triphenylamine hybrid conjugated systems have been synthesized and characterized. Their solid films exhibit an amorphous character and, in the case of $\mathbf{1}$, the UV-vis spectrum exhibits a broad band of weak intensity consistent with enhanced $\pi-\pi$ intermolecular interactions in the solid state. OFET and photovoltaic (PV) devices incorporating these compounds have been fabricated. While the measured hole mobilities are much lower than those obtained on OFETS based on several TTF derivatives, the first results obtained on heterojunction solar cells are comparable to the present state-of-the-art for cells made with TTF-based donor materials.

\section{Acknowledgments}

The authors thank Dr. Stephan Kirchmeyer (HC Stark) for generous gift of Baytron. They thank the SCAS of Angers for analytical experiments; in particular, Dr S. Fournier for HRMS.

\section{References}

[1] C.J. Brabec, N.S. Sariciftci, J.C. Hummelen, Adv. Func. Mater. 11 (2001) 15.

[2] H. Spanggaard, F.C. Krebs, A brief history of the development of organic and polymeric photovoltaics, Sol. Energy Mater. Sol. Cells 83 (2004) 125.

[3] S. Günes, H. Neugebauer, N.S. Sariciftci, Chem. Rev. 107 (2007) 1324.

[4] C. Lungenschmied, G. Dennler, H. Neugebauer, S.N. Sariciftci, M. Glatthaar, T. Meyer, A. Meyer, Sol. Energy Mater. Sol. Cells 91 (2007) 379.

[5] F.C. Krebs, H. Spanggard, T. Kjær, M. Biancardo, J. Alstrup, Mater. Sci. Eng. B 138 (2007) 106.

[6] G. Li, V. Shrotriya, J. Huang, Y. Yao, T. Moriarty, K. Emery, Y. Yang, Nat. Mater. 4 (2005) 864.

[7] W. Ma, C. Yang, X. Gong, K. Lee, A.J. Heeger, Adv. Funct. Mater. 15 (2005) 1617.

[8] M. Reyes-Reyes, K. Kim, J. Dewald, M. Lópex-Sandoval, A. Avadhanula, S. Curran, D.S. Carrol, Org. Lett. 7 (2005) 5749.

[9] J. Roncali, P. Leriche, A. Cravino, Adv. Mater. 19 (2007) 2045.

[10] A. Cravino, S. Roquet, O. Alévêque, P. Leriche, P. Frère, J. Roncali, Chem. Mater 18 (2006) 2584

[11] S. Roquet, A. Cravino, P. Leriche, O. Alévêque, P. Frère, J. Roncali, J. Am. Chem. Soc. 128 (2006) 3459.

[12] A. Cravino, P. Leriche, O. Alévêque, S. Roquet, J. Roncali, Adv. Mater. 18 (2006) 3033.

[13] P. Leriche, P. Frère, A. Cravino, O. Alévêque, J. Roncali, J. Org. Chem. 72 (2007) 8332.

[14] $\pi$-functional precursors: synthetic approaches (TTF and beyond), Chem. Rev. 11 (2004) 5057 (special issue, guest editor P. Batail).

[15] J.L. Segura, N. Martín, Angew. Chem. Int. Ed. 40 (2001) 1372.

[16] M. Mas-Torrent, C. Rovira, J. Mater. Chem. 16 (2006) 433.

[17] A. Naraso, J.I. Nishida, S. Ando, J. Yamaguchi, K. Itaka, H. Koinuma, H. Tada, S. Tokito, Y. Yamashita, J. Am. Chem. Soc. 127 (2005) 10142.

[18] M. Mas Torrent, M. Durkut, P. Hadley, X. Ribas, C. Rovira, J. Am. Chem. Soc. 126 (2004) 984.

[19] H.J. Lee, J. Sohn, J. Hwang, S.Y. Park, Chem. Mater. 16 (2004) 456.

[20] P. Leriche, S. Roquet, N. Pillerel, G. Mabon, P. Frère, Tetrahedron Lett. 44 (2003) 1623.

[21] P. Frère, P.J. Skabara, Chem. Soc. Rev. 34 (2005) 69

[22] Y. Shirota, J. Mater. Chem. 15 (2005) 75.

[23] S.M. Sze, Physics of Semiconductor Devices, Wiley, New York, 1981.

[24] Y. Yamashita, W. Takashima, K. Kaneto, Jpn. J. Appl. Phys. 32 (1993) 1017.

[25] R. Berridge, P.J. Skabara, C. Pozo-Gonzalo, A. Kanibolotsky, J. Lohr, J.J.W. McDouall, E.J.L. McInnes, J. Wolowska, C. Winder, N.S. Sariciftci, R.W. Harrington, W. Clegg, J. Phys. Chem. B. 110 (2006) 3140.

[26] N. Martin, L. Sanchez, M.A. Herranz, B. Illescas, D.M. Guldi, Acc. Chem. Res. 40 (2007) 1015.

[27] C.J. Brabec, A. Cravino, D. Meissner, N.S. Sariciftci, T. Fromherz, M.T. Rispens L. Sanchez, J.C. Hummelen, Adv. Funct. Mater. 11 (2001) 374

[28] A. Gadisa, M. Svensson, M.R. Andersson, O. Inganäs, Appl. Phys Lett. 84 (2004) 1609. 